\title{
An exploratory study of teachers' subjective wellbeing: Understanding the links between teachers' income satisfaction, vocation, self-efficacy and work satisfaction
}

\section{Authors:}

1. Huan Song, Faculty of Education, Beijing Normal University, N.19 Xin Jie Kou Wai Street, Haidian District, Beijing, P.R.China 100875. Email: songhuan@bnu.edu.cn

2. Qing Gu, London Centre for Leadership in Learning, University College London Institute of Education, 20 Bedford Way, London WC1H 0AL, UK Email: q.gu@ucl.ac.uk

3. Zhonghua Zhang, Melbourne Graduate School of Education, Kwong Lee Dow Building, 234 Queensberry Street, The University of Melbourne, 3010, Australia. Email: zhonghua.zhang@unimelb.edu.au

\section{Corresponding Author:}

\section{Professor Qing Gu}

Address: London Centre for Leadership in Learning, University College London Institute of Education, 20 Bedford Way, London WC1H 0AL, UK

Email: q.gu@ucl.ac.uk

\begin{abstract}
This article examines the nature of teachers' subjective wellbeing. Drawing upon the survey evidence from a three-year mixed methods study in China, the article explores the dynamic interaction between key aspects of teachers' subjective wellbeing: altruism and self-efficacy (psychological functioning) and work satisfaction and income satisfaction (cognitive dimension). The results show that although teachers' judgement of the quality of life in their workplaces reflects the strengths of their altruistic values and their capacity to fulfil these values, such judgement is adversely moderated by their income satisfaction. The research adds new evidence to current debate on the quality retention of teachers.
\end{abstract}




\section{Keywords}

Teacher subjective wellbeing; self-efficacy; work satisfaction; income satisfaction; teacher retention; altruism 


\section{Introduction}

Interest in teacher wellbeing is not new and not surprising, driven partly by research which confirms that teaching is inherently an intellectually, physically and emotionally demanding job (Huberman, 1993; Day \& Gu, 2010, 2010). Research shows that how teachers feel about their lives and the extent to which they are satisfied with the quality of their day-to-day experience (i.e. their subjective wellbeing) can have profound implications for their practices, their retention decisions, and perhaps most importantly, the learning and achievement of their pupils (OECD, 2017; Pyhältö, Soini, \& Pietarinen, 2010). Although much has been written about teacher wellbeing (e.g. Carrasco \& Bernal, 2008; Day \& Gu, 2009; Marchesi, 2007), robust evidence about the measurement of their subjective wellbeing remains relatively underrepresented in the literature. This paper reports quantitative findings of the exploratory phase of a three-year mixed methods study on teacher wellbeing in China. The guiding research question for this strand of investigation was: How do the key components of teachers' subjective wellbeing relate to each other?

Using the structural equation modelling (SEM) analysis, the paper explores the dynamic associations between key psychological (i.e. altruistic values, self-efficacy beliefs) and cognitive (i.e. income satisfaction, work satisfaction) components of teachers' subject wellbeing, and investigates how such associations were moderated by teachers' basic living standards - as measured by the average salary in the same geographic areas. Each SEM model presented in the paper shows that teachers' judgement of the quality of their lives in the workplace represents a composite outcome of the interactions between various wellbeing measures. Thus, rather than examining what predicts teachers' subjective wellbeing, this paper focusses on exploring the plausible interactive interrelationships between key components of wellbeing. The results highlight the importance of understanding the ways in which various wellbeing components (or measures), individually and interactively, influence each other in differing circumstances, and through this, contribute to the continuously building literature on developing nuanced measurements of how teachers evaluate the quality of their work and lives in schools.

\section{The Science of Subjective Wellbeing}


Scientific attention to subjective wellbeing has only increased exponentially since the early 1980s alongside the burgeoning growth in the field of positive psychology. Diener and his colleagues (1999), whose ground breaking work has significantly advanced understandings of subjective wellbeing over the last three decades, argue that growth in the field of subjective wellbeing 'reflects larger societal trends concerning the value of the individual, the importance of subjective views in evaluating life, and the recognition that well-being necessarily includes positive elements that transcend economic prosperity' (1999: 276). To date, research into this field suggests that people's evaluations and feelings about their lives matter not only as an end itself, but also as causes of many desirable economic, social, organisational and health outcomes (Diener \& Seligman, 2004; The Children's Society, 2015 \& 2016).

Because wellbeing has been used in varying contexts, cultures and disciplinary traditions to mean rather different things to different people (Lucas, 2007; OECD, 2013, 2015a \& 2017; Tov \& Diener, 2007), there has been concerted effort by scholars to define the meaning and measurement of how people evaluate and feel about their wellbeing. First, rather than a single specific construct, subjective wellbeing is believed to be best perceived as 'a broad category of phenomena' and a general area of scientific interest (Diener et al., 1999: 277). The endeavour to create a composite and comprehensive measure of life evaluation overall has led many to recognise that each specific construct of the global judgements of life satisfaction, as well as the associations between them, needs to be understood in their own right (Denier et al., 1999). Also, depending on researchers' disciplinary traditions and methodological preferences, different measures assess different aspects of subjective wellbeing (Pavot \& Diener, 2008). Moreover, people's self-evaluation of life satisfaction - a strong component of subjective wellbeing - is not only dependent on individuals' personalities, but also the culture and context, and thus the 'time' and 'place' in which they live (Diener et al., 1999 \& 2017; OECD, 2017).

Second, research in the field has established that subjective wellbeing typically encompasses at least two key components: i) people's cognitive judgements about the quality of their life as a whole (i.e. life satisfaction) or particular aspects or domains of their lives (i.e. domain satisfaction), and ii) affective experiences of positive and negative emotions. Both components are regarded as the 'hedonic' aspect of subjective experience 
which focusses on one's happiness, pleasure and satisfaction in life (Diener et al., 1999; Diener, Lucas \& Scollon, 2006; Kahneman \& Krueger, 2006; OECD, 2013; The Children's Society, 2013 \& 2016). Research exploring the wider context effects on the fluctuation of subjective wellbeing suggests that whilst life evaluations tend to remain relatively more stable over time, the affective experience, such as momentary mood, is more likely to respond to relatively ephemeral changes of the environment (Helliwell, Layard, \& Sachs, 2015; Helliwell \& Wang, 2011; Lucas \& Lawless, 2013; OECD, 2013). Given this, it is perhaps no surprise that some scholars suggest that self-reported measures of life satisfaction are more stable indicators of subjective wellbeing than self-reports of affective states (e.g. Gilman et al., 2008; OECD, 2017; The Children's Society, 2013).

Third, a notable difference in scholarly approaches to conceptualising subjective wellbeing is whether psychological flourishing should also be considered as a third essential component of subjective wellbeing. Although many recent studies continue to treat the hedonic aspect of experience as subjective wellbeing (e.g. The Children's Society, $2013,2016)$, increasingly researchers have highlighted the importance of recognising the eudaimonic aspect of subjective wellbeing, driven by a more instrumental focus on achieving one's potential through fully exercising their human capacities and capabilities (Haybron, 2008; OECD, 2013). As Ryan and Deci (2001), Seligman (2011), Huppert and So (2013), and Bullough and his colleagues (Bullough \& Pinnegar, 2009; Bullough \& HallKenyon, 2018) have all argued in their latest work, self-evaluations of life going well must encompass a combination of feeling good and functioning effectively, because competence, autonomy, goal orientation, and sense of purpose - all of which are key components of psychological wellbeing - can have a significant effect on life satisfaction and positive affect. Drawing upon the latest empirical research and conceptual developments in the field, the Guidelines on Measuring Subjective Wellbeing (OECD, 2013) propose a three dimensional organising framework of subjective wellbeing:

- life satisfaction: income satisfaction, health satisfaction, work satisfaction

- affect: anger, worry, happiness

- eudaimonic wellbeing: competence, autonomy, meaning and purpose

Taken together, research over the last three decades suggests that 'subjective well-being is an umbrella term for the different valuations people make regarding their lives, the 
events happening to them, their bodies and minds, and the circumstances in which they live' (Diener, 2006). These internally experienced evaluations are subjective in that they relate to good mental and psychological functioning and denote people's cognitive assessment and affective reactions to the pleasantness and desirability of the quality of their lives (Diener et al., 2010 \& 2017; Huppert \& So, 2013; OECD, 2013). These developments provide useful conceptual and empirical bases for our exploratory research of teachers' subjective wellbeing.

\section{A Working Definition of Teachers' Subjective Wellbeing}

Building upon OECD's (2015a \& 2017) latest definition, we take a broad working definition of teachers' subjective wellbeing as teachers' self-reported experience and assessment of the quality of their working lives and the sense of purpose and capabilities that they need to live a happy and fulfilling life as a teacher.

This working definition of teachers' subjective wellbeing is intended to encompass the three key aspects of subjective wellbeing (i.e. cognitive judgements, affective experience, and psychological functioning and flourishing) that behavioural and social sciences research has widely identified, and also, and most importantly, to reflect the aspects of teachers' work and lives that are experienced by them as fundamental to understanding of their commitment, perceived and measured effectiveness in the classroom and retention decisions. The reference to sense of purpose, capabilities and fulfilment should be considered to explicitly reflect the influence of intrinsic values and efficacy beliefs on teachers' capacity to teach to their best over time and subsequently, the extent to which they feel rewarded and satisfied with their work and achievement in the profession. The relationship between purpose, efficacious beliefs, capabilities and fulfilment has been well documented in empirical research on teachers and teaching, and is considered at the heart of the broad construct of teacher subjective wellbeing in our research.

In the initial exploration phase our research has focussed on identifying key components (or measures) of each of the three cognitive, affective and psychological dimensions of subjective wellbeing and the relationship between them. Given the complex and dynamic nature of people's subjective perceptions of their lives, the empirical and conceptual challenge has been to decide which components to be included in the overall wellbeing 
framework that best reflects the meaning and purpose of the work and lives of teachers. Because of the limitation of space, in this paper we focus on exploring the dynamic interrelationship between four components of teachers' subjective wellbeing: altruism and self-efficacy (psychological functioning), and work satisfaction and income satisfaction (cognitive dimension), and how such relationship may vary when income and living standards are considered. The decision to exclude the affective dimension in this paper is also related to the challenge of producing and collecting reliable measures in the initial phase of this research, especially given the unstable and time-sensitive nature of affect and emotions (e.g. pleasant-unpleasant affect, discrete emotions such as anxiety and sadness). More discussion on this methodological consideration will be addressed in the discussion later.

The identification of the four components is grounded in the research literature on teacher quality and retention in that all express teachers' own assessment of aspects of their lives in teaching. The organising approach is also consistent with the OECD's (2013) guiding framework for subjective wellbeing. The rationale to treat work satisfaction as a plausible outcome variable in exploring the interrelationships between the components was informed by the existing research which suggests that teacher self-efficacy is significantly related to (and can predict) teacher job satisfaction (Skaalvik \& Skaalvik, 2010), and that teachers' satisfaction with their work and professional lives contributes to their turnover decisions and outcomes at both school (e.g. organisational commitment) and student (e.g. academic achievement) levels (Bogler, 2002; Ingersoll, 2002; Shen et al., 2012).

\section{Altruism}

Altruism as a philosophical concept has long been used in education to describe an ethical principle and moral purpose that drive many teachers to build caring relationships with their students (Nias, 1989; Noddings 1992), and remain committed and passionate about giving their best to the students whom they serve (Ayers, 2010; Day, 2004; Gu \& Li, 2013; Hansen, 1995; Nieto, 2003 \& 2015). Such passion and the emotional, spiritual and intellectual fulfilment that teachers are able to derive from their students' learning and achievement have led many scholars to argue that teaching is inherently a vocation or a calling (Day \& Gu, 2010 \& 2014; Hansen, 1995; Huberman, 1993; Palmer, 2007). 
Recognising how these inner rewards motivate teachers to improve their ability to teach well is integral to developing a nuanced understanding of why altruism is essential in teaching. To view teaching as an 'altruistic vocation' (Schwarz \& Alberts, 1998: 155) is not, as sceptics might argue, an unsustainable 'ethical ideal' which requires teachers to sacrifice a high degree of selflessness (e.g. Higgins, 2011). Nor does it deny that teachers' material needs (such as pay and income) are important. Rather, this view 'turns the focus of perception in such a way that the challenges and the complexity in teaching become sources of interest in the work, rather than barriers or frustrating obstacles to overcome' (Hansen, 1995: 144). Such a view of teaching leads to a positive and productive emphasis on learning, growth and development - which regards teachers' need for intellectual challenge and capacity building as an indispensable part of their moral responsibility. It reveals profoundly that the good life of teaching entails both an intellectual act and a moral enterprise (Goodlad, Soder, \& Sironik, 1990; Hansen, 1995).

\section{Self-efficacy}

Bandura's (1986) social cognitive theory defines perceived self-efficacy as individuals' beliefs about their capabilities to exercise control over events that affect their lives, to produce expected performance, and to influence others. People with strong beliefs in their capabilities make things happen by setting themselves challenging goals, thinking strategically in the face of difficulties, and remaining resilient, motivated and taskfocussed (Bandura, 1997). Bandura (1997) thus rejects the view that that efficacy beliefs are mere inert predictors of performance accomplishment. Rather, he argues that they are key contributors to effective functioning and human flourishing.

Bandura's argument, together with findings from the latest research on teachers' selfefficacy (e.g. Klassen, Tze, Betts, \& Gordon, 2011; Renshaw, Long \& Cook, 2015; Zee \& Koomen, 2016), offers new conceptual and empirical ground for our decision to treat teachers' efficacy beliefs as a key sub-construct (as opposed to predictor that has been used widely in wellbeing research) of their subjective wellbeing. Teachers' efficacy beliefs are their self-referent judgments of their own capacity and capability to perform at certain levels (Kelley \& Finnigan, 2003; Zee \& Koomen, 2016). 
Over the last thirty years research has consistently reported that self-efficacious teachers tend to suffer less emotional exhaustion and burnout symptoms, and experience higher levels of responsibility for teaching, commitment, personal accomplishment, and job satisfaction (e.g. Klassen \& Chiu, 2010; Pillay, Goddard, \& Wilss, 2005; Skaalvik \& Skaalvik, 2010; Schwerdtfeger, Konermann, \& Schonhofen, 2008; Zee \& Koomen, 2016). These findings lend support for the view that the strengths of teachers' judgements of their performance capability do not directly determine their overall subjective wellbeing. Rather, they enhance, or constrain, the strengths of their aspiration, commitment, and effort to fulfil different task demands in given circumstances and through these, influence, positively or negatively, their emotional/affective outlook and satisfaction with work life. Thus, we argue that how teachers feel about their wellbeing in the workplace is inherently influenced by their efficacy beliefs, but that such influence is achieved through impacting on their affective reactions to the success (or failure) of their performance and how they make of their life at work.

\section{Work satisfaction}

Despite deep criticism of an increasingly rigid performativity culture and accountability demands in schools, research tends to show that the vast majority of teachers are satisfied with their jobs overall (Day et al.,, 2007; OECD, 2005b, 2014). The strengths of their ethics of care and commitment, efficacy beliefs, and in-school support of their professional growth, individually and collectively, have much to explain the extent to which teachers may continue to feel satisfied with the work that they do with children (Bogler, 2002; Caprara et al., 2006; Nieto, 2015; OECD, 2016; Wu \& Short, 1996). In this sense, teachers' job satisfaction is not only an outcome of the social and intellectual contexts of their workplaces, but also an important contributor that influences their motivation, commitment and retention decisions (e.g. Evans, 1997; Skaalvik \& Skaalvik, 2011). Research on wellbeing has found substantive evidence showing that experiencing higher satisfaction on the job is reliably associated with better performance, higher levels of organisational citizenship and lower turnover (e.g. Carsten \& Spector, 1987; George, 1990; Miles et al., 2002; Spector, 1997).

In our research work satisfaction is considered as a satisfying state of mind which is closely associated with the reward that teachers derive from students'success and their evaluations 
of the work environments in terms of developing their capabilities to bring about such success. It also entails an indispensable emotional dimension of 'happiness' and fulfilment derived from an intrinsic commitment to teaching. It is important to note that 'happiness' and 'satisfaction' do not have the same meaning in different languages and cultures (Diener et al., 1999; Veenhoven, 2000). For the Chinese, the lay theories of happiness emphasises fulfilment of social role obligations and achieving a dialectical balance between happiness and unhappiness - which is in stark contrast to the Euro-American conception that emphasises 'personal accountability and explicit pursuit of personal goals' (Lu, 2010, p. 333). The element of 'feeling happy as a teacher' in our conceptualisation of work satisfaction is grounded in a Confucian collective, moral discourse and must be understood as entailing teachers' pursuit of their moral duties for the society. Thus, an advantage of using the term work satisfaction over job satisfaction is that it emphasises the altruistic nature of teaching and a Chinese culturally embedded meaning of happiness - both of which denote that carrying out the work of teaching is larger than a job.

\section{Income satisfaction}

Scholars have used different social and economic theories to explain the complex relation between money and subjective wellbeing. Among them, Veenhoven's (1991) absolute theory assumes a relationship between basic needs satisfaction and subjective wellbeing, emphasising the existence of a threshold level - at which the effects of rising incomes become trivial. Research reviews by Ahuvia (2008) and Diener and Seligman (2004) also suggest that once the fulfilment of basic needs are satisfied, differences in wellbeing are more likely to be influenced by factors such as supportive social relationships and enjoyment at work than increases in income. Moreover, Ferrer-i-Carbonell's $(2002,2005)$ work points to an additional 'relative utility' effect in the analysis of individual subjective wellbeing. She argues on the basis of German panel data that individuals tend to be happier if their income is greater than that of the reference group because the 'comparison income' effect 'reflects the importance of the relative position of individuals in society for their satisfaction with life' (2002: 999).

Much social and economic evidence on the 'basic threshold' and 'relative' effects of income has contributed to the debate of the importance of monetary incentives to teacher 
recruitment and retention. Some research found that higher teacher salaries were positively associated with teachers' length of stay in the profession (Dolton \& van der Klaauw, 1995; Murnane \& Olsen, 1989, 1990). Teachers leave if they are not able to make a decent living or when they do not make competitive salaries, especially for those in hard-to-recruit subjective areas (Firestone, 2014; Hanushek, 2006; Ingersoll \& May, 2012; Johnson \& Birkeland, 2003). Other studies, however, reported that raising teachers' salaries had failed to improve either the size or the quality of the teaching workforce (de Ree et al., 2015; Goldhaber, 2001; Hanushek, 2006; Loeb \& Page, 2000). Over the last decade compelling evidence on the limited effects of performance-based pay incentives on teacher motivation or their practices (Firestone, 2014; Murnane \& Cohen, 1986; Yuan et al., 2013) highlights the intricate and complex connection between income and teachers' work, lives and effectiveness, and reinforces a need to examine teachers' income satisfaction in relation to factors such as their values and efficacy beliefs that can influence how the connection plays out in teachers' lives.

\section{The Research}

This paper reports the results of a large scale survey amongst more than 1,500 teachers in the eastern areas of China. The survey research features an initial exploratory phase of a three-year mixed methods research project (2017-2020) designed to investigate how teachers in the eastern regions of China judge the quality of their professional lives, and the ways in which their judgement is influenced by a range of anticipated and unanticipated personal, workplace and broad policy factors over the course of their professional lives. The research question that guided the exploratory phase of the project was: How do the key components of teachers' subjective wellbeing relate to each other? The design of the survey focussed on exploring the interactive and dynamic relationship between the key components of teachers' subjective wellbeing. It draws attention to whether and how teachers' altruistic values to teach, beliefs in their ability to teach well (i.e. their self-efficacy), and their income satisfaction - all of which are found to have significant influence on their quality and retention decisions - influence their satisfaction with their working life as a teacher.

\section{The survey design}

Using the structural equation modelling analysis, the survey tested the joint relationships 
among teachers' income satisfaction, altruistic values, self-efficacy beliefs, and work satisfaction. We hypothesised that although income satisfaction may have a direct relationship with work satisfaction, the 'basic threshold' and 'relative effects of income' may exist in how teachers evaluate the quality of their work and lives: the relationship between teachers' income satisfaction and work satisfaction differs based on their levels of income (as compared to the average salary in their regions), and also, is moderated by the strengths of their altruistic values and efficacy beliefs. In particular, informed by the existing research, we hypothesised four sets of interrelationships amongst the key components:

(1) Teachers' altruistic values and self-efficacy beliefs influence their work satisfaction directly and positively (e.g. Gu \& Li, 2013; Canrinus et al., 2012; Caprara et al., 2006; Judge et al., 2005): teachers with stronger altruistic values of teaching and with higher self-efficacy beliefs tend to report greater satisfaction with work.

(2) The relationship between teachers' income satisfaction and work satisfaction is adversely moderated by the strength of their altruistic values (e.g. Day \& Gu, 2010; Demirel, 2014; Firestone, 2014; McKinney, 2000): the stronger teachers feel vocationally committed to teaching, the weaker influence their income satisfaction has on the satisfaction they derive from their work.

(3) The influence of income satisfaction on work satisfaction is also negatively moderated by the strengths of teachers' efficacy beliefs (e.g. von der Embase et al., 2016; Zee \& Koomen, 2016): the effects of income satisfaction on work satisfaction is stronger for teachers with lower levels of self-efficacy beliefs; and conversely, for teachers with high self-efficacy beliefs, their work satisfaction is less likely to be affected by their income satisfaction.

(4) The moderating effects of altruistic values and self-efficacy beliefs on the relationship between teachers' income satisfaction and work satisfaction only exist when teachers' salary income is above the regional teacher average salary (i.e. when their income is above certain thresholds) (e.g. Firestone \& Pennell, 1993). According to OECD (2015b), teachers' salary in China is 3,111 RMB per month (approximately 312 GBP) which is similar to the average teacher salary in the eastern regions of China (approximately 3,000 RMB per month). Given this, the research used 3,000 RMB as a baseline to divide the participants into two 
groups: the low-income group (<=300 GBP) and the above-average-income group (> 300 GBP).

\section{Participants}

Participants for this study were teachers of state primary and secondary schools in the eastern areas of China. Random invitations to participate were sent out to 2,000 teachers in three provinces (Liaoning, Shandong, and Guangdong) and one municipality (Beijing). A total of 1,525 teachers from 103 primary and secondary schools responded to the survey. The demographics of the survey participants are summarised in Table 1.

$<$ Insert Table 1 here $>$

\section{Measures}

Questionnaire measures were developed on the basis of established scales that were used and published in various studies on altruism, income satisfaction, self-efficacy, and work satisfaction.

\section{Altruism}

The 4-item Teacher Altruism Scale developed for Chinese teachers (Xu, 2007; Zheng, Yang \& Ling, 2014) was used to assess teachers' altruistic values. These items asked the teachers to evaluate the extent to which altruistic values and vocational responsibility have played a role in their decision to become a teacher. All the items were measured on a 5-point scale ranging from 1 (not important at all) to 5 (very important). A sample item is 'Teachers care for students'.

\section{Self-efficacy}

Teacher self-efficacy was measured using a modified version of the teacher efficacy scale developed by Hoy and Woolfolk (1990). This scale assessed teachers' personal beliefs in their capacity to make a positive difference to students' learning and achievement. The scale is composed of eight items that are measured on a 6-point Likert scale ranging from 1 (strongly agree) to 6 (strongly disagree). All the original questionnaire statements were negatively phrased (e.g. 'I have found students rather sophisticated and difficult to communicate with.'). In the data analysis the scales were reversed so that higher scores indicated more positive responses. 


\section{Work satisfaction}

Three items were used to measure teachers' judgement of the quality of their work life. They were adapted from the Satisfaction with Life Scale (SWLS) (Diener, Emmons, Larsen, \& Griffin, 1985) which was created to give a unitary assessment of individuals' selfevaluations of the quality of life. The revised items intended to assess teachers' satisfaction with teaching as a profession, and with the overall circumstances of their work. Considering the cultural significance of 'happiness' in the Chinese society, a third item on the scale was adapted to ask participants to think about their role as a teacher and whether they felt happy in the job overall ('I am content with my role as a teacher and all it involved.'). The three items are measured on a five Linkert scale, ranging from 1 (very untrue of me) to 5 (very true of me).

\section{Income satisfaction}

Teaches' income satisfaction was assessed using an adapted three-item sub-scale from the Teacher Job Satisfaction Scale developed by Xu and Zhang (2011) in China which showed strong construct validity and high internal consistency. In the present research, the adapted items asked teachers to assess their income satisfaction in relative terms, indicating the extent to which they were satisfied with their income compared to teachers in other schools and to other professions (e.g. 'My salary as a full-time school teacher is fair compared to teachers in other schools.'). In order to explore whether there is a 'basic threshold' effect on the relationship between teachers' income satisfaction and work satisfaction, participants were also asked to respond to a third item which assessed their absolute satisfaction with the overall material welfare and income that they receive as a teacher. Teachers were asked to report their self-evaluations on a 5-point Likert scale ranging from 1 (strongly disagree) to 5 (strongly agree).

\section{Data analysis}

To test the aforementioned four sets of hypothesised relationships, the analyses were conducted in five broad steps.

In Step 1, confirmatory factor analysis (CFA) was used to test the construct validity of the scales measuring the four key latent variables of teachers' subjective wellbeing: income 
satisfaction, work satisfaction, altruism, and self-efficacy. Based on the goodness of fit indices of the CFA models, composite reliability coefficients $(\omega)$ were calculated using the parameters estimated from each of the CFA models (Raykov, 2004) to examine the reliability of the measures in Step 2.

In Step 3, a theoretical model was tested using structural equation modelling (SEM) to explore the interrelationships between the four latent variables (hypothesis 1). The results enabled us to further explore a second theoretical SEM model which examined the moderating effects of altruism and self-efficacy on the prediction of income satisfaction to work satisfaction (hypotheses 2 and 3) in Step 4. To explore their specific effects, two structural regression paths were added to the first SEM model:

- one path explored how altruism may influence the ways in which income satisfaction predicts work satisfaction, which examines the moderating effect of altruism on the relationship between income satisfaction and work satisfaction;

- the other path considered the ways in which self-efficacy may influence how work satisfaction is predicted by income satisfaction, which tests the moderating role of self-efficacy in the impact of income satisfaction on the work satisfaction.

Statistical significance tests and the goodness of fit indices were used to examine whether the moderating effects of the two structural regression paths were present in the second SEM model.

Step 5 explored whether the interrelationships between the four latent constructs identified in the second SEM model were different between the low-income group $(<=3,000)$ and the above-average-income (>3000) group (hypothesis 4$)$. Measurement invariance properties of the latent constructs were tested first to examine whether the same latent constructs could be defined for each of the two groups. This was achieved through a series of sequential multiple-group CFA analyses. The configural invariance model, which assumed that the number of factors and the pattern of item-factor relationships were identical across the two groups, were tested first, followed by exploration of a metric invariance (weak invariance) model which assumed that the factor loadings were equal across the two groups. We then further constrained the equality of the item intercepts across the two groups for the metric invariance model to explore 
whether the strong invariance property could be supported. Once this was achieved, we tested the strict invariance property for the measures across the two groups which set additional constraints on the equality of the error variance-covariance of the items between the two groups. The follow-up measurement invariance analysis assumed that the factor variance-covariances were also identical across the two groups based on support for the strict invariance model. The last measurement invariance test involved the latent means invariance which assumed that there were no statistically significant differences on the four latent variables between the two groups. Finally, we fitted the model that was tested in Step 4 to each of the two groups to examine whether the relationships among the four latent constructs were different between the two groups.

All the analyses were conducted with the robust maximum likelihood estimation method (MLR) using the computer software Mplus Version 6.1 (Muthén and Muthén, 2008-2011). With MLR, the standard errors of the parameter estimates as well as the tests of fit were corrected in relation to the non-normality of observations and categorical nature of the variables (Yuan and Schuster, 2014). In addition, in order to control the clustering effect due to the nested structure of the data (i.e., teachers nested with schools), the Mplus complex survey design option was used in the analyses (Muthén \& Satorra, 1995; Muthén and Muthén, 2008-2011).

Multiple goodness-of-fit indices were used in this study to assess the fit of all structural models. They included the chi-squared test of significance $\left(\chi^{2}\right)$, the comparative fit index (CFI; Bentler, 1990), the Tucker-Lewis index (TLI; Tucker \& Lewis, 1973), the Root Mean Square Error of Approximation (RMSEA; Browne \& Cudeck, 1992), and the Standardized Root Mean Residual (SRMR). Model fit to the data was considered acceptable if the values of CFI and TLI were greater than .95 and the values of RMSEA were less than .08 (Hu \& Bentler, 1999; Marsh, Hau, \& Wen, 2004). In addition, two more indices, the Akaike information criterion (AIC; Akaike 1974) and the Bayesian information criterion (BIC; Schwarz, 1978), were used to compare models. Smaller AIC and BIC values are indicative of better fitting models in terms of model fit and parsimony.

\section{Results}

Preliminary analysis 
The means and standard deviations of the four latent variables are presented in Table 2 . All the means of the four variables are greater than their respective median points, indicating teachers' positive attitudes towards each of the four constructs.

\section{$<$ Insert Table 2 here $>$}

\section{Measurement models: CFA analyses}

To test the construct validity of the scales which measure each of the four latent variables, a four-factor CFA measurement model was explored. The goodness-of-fit indices indicated acceptable model fit to the data $\left(x^{2}=1007.421, \mathrm{df}=129 ; \mathrm{CFI}=.948\right.$; $\mathrm{TLI}=.938$; RMSEA $=.067,90 \%$ CI $(.063, .071))$. However, the modification indices suggested that the model fit indices could be substantially improved if the residuals between the two items measuring altruism ("Teachers care for students." and "Teachers should have a strong sense of responsibility to students."), between the two items measuring self-efficacy ("I have limited influence on most of my students because their motivation for learning is shaped by their family backgrounds." and "I have limited influence on most of my students because their performance is determined by their family backgrounds."), and between another two items measuring self-efficacy ("My influence on students' motivation for learning is less compared to their classmates." and "I feel that some of my students have hardly made any progress.") were allowed to be correlated respectively.

A new four-factor CFA model which allowed for the free estimations of the three residual correlations was then explored. The goodness-of-fit indices suggested the fit of the revised four-factor model was very good $\left(x^{2}=593.436, \mathrm{df}=126\right.$; $\mathrm{CFI}=.972$; TLI = .966; RMSEA $=.049,90 \% \mathrm{CI}(.045, .053))$. The estimates of the standardized factor loadings for the 18 items, ranging from .726 to .968 , suggested strong relationships between the items and their respective latent factors that they measured. Given its better fit to the data, this revised four-factor CFA measurement model was used in the following analyses.

Table 2 presents the scale score composite reliability coefficients for the four latent measures, ranging from .870 (Income satisfaction) to .951 (Altruism). It also shows the inter-correlations among the four latent factors. As expected, altruism, income satisfaction and self-efficacy have significant correlations with work satisfaction. The correlation amongst almost all the latent constructs were statistically significant, ranging 
from 0.128 (weak) to 0.572 (moderate). Altruism showed no significant correlations with income satisfaction - which supports our observation from the literature review that teaching, for many teachers in the profession, is larger than a job.

The relationships between teachers' income satisfaction, altruistic values, self-efficacy, and work satisfaction

The SEM model in Figure 1 explored the relationship specified in the first hypothesis. All indices generally support a good fit of the model to the data $\left(x^{2}=604.026, d f=127\right.$; CFI $=.972 ; \mathrm{TLI}=.966 ; \mathrm{RMSEA}=.050,90 \% \mathrm{CI}(.046, .054) ; \mathrm{AIC}=63768.228 ; \mathrm{BIC}=64098.672)$. The estimates of the standardized structural regression coefficients are presented in Table 3 (See also Figure 1). As expected, the model suggests that teachers' altruistic values and self-efficacy beliefs affect their assessment of the quality of life in teaching directly and positively. However, these effects are relatively much weaker compared to the influence of income satisfaction on teachers' work satisfaction - which is itself a most interesting finding in our study.

<Insert Table 3 here>
<Insert Figure 1 here>

In addition, the relationship between altruism and work satisfaction can be moderated by the strength of teachers' efficacy beliefs: altruism has an effect on self-efficacy which in turn influences work satisfaction positively. This indirect path shows that considering the strengths of efficacy beliefs is necessary in understanding how values influence teachers' satisfaction with the quality of their work. Although teachers' altruistic and vocational values influence their work satisfaction, such positive influence may also be achieved indirectly through enhancing beliefs in their capacity to master the challenges in teaching and to continue to teach well.

The moderating effects of teachers' altruistic values and self-efficacy on the relationship between income satisfaction and work satisfaction

In order to understand the ways in which income satisfaction influences teachers' work satisfaction in more detail, we added two new latent constructs to the first model: one representing the interaction between the two latent variables of altruism and income satisfaction, and the other the interaction between self-efficacy and income satisfaction. 
The Latent Moderated Structural Equations (LMS) method was used to test the SEM models (LMS, Klein \& Moosbrugger, 2000; Klein \& Muthén, 2007). The values of AIC and BIC - the two information criterion indices that were sought for model fit testing - were 63724.535 and 64065.639 respectively. They were smaller than those estimated in Model 1, indicating that the new SEM interaction model has a better fit to the data. The standardized structural regression coefficients, which were calculated according to Wen, Marsh, and Hau (2010), are shown in both Table 3 and Figure 2. The results revealed statistically significant and negative effects that the two new latent interaction variables have on teachers' work satisfaction: i) the interaction between altruism and income satisfaction $(\beta=-.100, p<.01)$; and ii) the interaction between self-efficacy and income satisfaction $(\beta=-.090, p<.01)$.

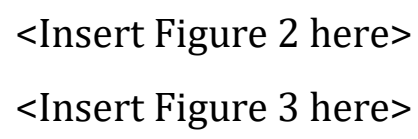

Both altruism and self-efficacy are important moderators of the relationships between income satisfaction and work satisfaction (also see Figure 3). First, the stronger teachers' altruistic values, the weaker the influence that income satisfaction has on work satisfaction. Second, and similarly, if teachers' efficacy beliefs are stronger, the influence that income satisfaction has their work satisfaction is likely to be weaker. Although the moderating effects are small, they are, nonetheless, statistically highly significant. This confirms that income satisfaction alone is not sufficient to explain how teachers judge the quality of their work lives: their altruistic values and efficacy beliefs to do the job well are both necessary.

Moderating effects of 'meeting average salaries': comparisons between low-income group and above-average-income group

The final analyses explored whether meeting average salaries within the geographic areas can have a moderating effect on the relationship between teachers' satisfaction with their income and satisfaction with their work. To achieve this, we split the teacher sample into two and produced two sub-SEM models: one for teachers whose salaries are above the regional average (hence 'above-average-income group'), and the other for those whose salaries are the same or below the regional average (hence 'low-income group'). Before 
comparing the two structural models, we conduced multiple-group tests of measurement invariance to examine whether the mean differences for each latent variable between the two groups can be interpreted as 'genuine' group differences - rather than due to bias in the latent constructs measured.

As the tests involved a series of nested models, adjusted chi-square tests were used to assess whether equality constraints placed on the two measurement models were statistically supported. Results in Table 4 show that the configural invariance, weak invariance, and strong invariance were all supported, suggesting that further comparative analyses of the two structural models could proceed. More specifically, with regard to the two latent variables of income satisfaction and work satisfaction, although the statistically significant result of adjusted chi-square difference tests suggests that the full strict invariance was untenable, the partial invariance was supported by freeing the error variances of the two latent variables to be distinct between the two groups. Similarly, with regard to income satisfaction and self-efficacy, although the full factor variancecovariance invariance was untenable, the partial measurement invariance - which allowed for the free estimation of the correlation between the two latent variables across the two income groups - was supported. Taken together, the results warrant the measurement invariances of the four constructs, suggesting that the same latent constructs could be defined for the two groups.

$<$ Insert Table 4 here>

The estimates of the standardized structural regression coefficients for the low-income group and the above-average-income group are presented in Table 3, and the SEM models for each of the two income groups are presented in Figures 4 and 5 respectively. Figure 5 shows that for the above-average-income group, the latent interaction variable, altruism x income satisfaction, has a statistically significant and negative effect on work satisfaction (as also conveyed in Figure 3). This is consistent with the observation identified from the total teacher sample, which also suggests that when teachers' salaries were above the average salaries in their geographic areas, the impact of income satisfaction on work satisfaction was weaker for those who reported stronger altruistic values in teaching. Conversely, those who reported weaker altruistic values tended to experience stronger effects of income satisfaction on their work satisfaction. The same statistically significant, 
negative effect was also identified for the latent interaction variable: self-efficacy $x$ income satisfaction, indicating that for the above-average-income group, those who reported stronger efficacy beliefs tended to perceive weaker effects of income satisfaction on their work satisfaction compared to those whose efficacy beliefs were less positive.

$<$ Insert Figures $4 \& 5$ here $>$

However, in contrast, neither of the altruism and self-efficacy was identified as significant moderator to the relationship between income satisfaction and work satisfaction for the low-income group (Figure 4). This is itself one of the most interesting and intriguing findings in this research, suggesting that when teachers' salary income was below the average in their region, for all teachers - irrespective of the strengths of their altruistic values or efficacy beliefs, their income satisfaction was the primary source of impact on their work satisfaction.

\section{Discussion}

The question of how to retain the heart, mind and effectiveness of teachers who work in an intellectually, emotionally and physically challenging place called 'school' (Goodlad, 2004) has been contemplated for many years in many countries. China is no exception. Over the last two decades, the Chinese education system has experienced a wide range of government-led, deep structural, cultural and curriculum reforms, designed to bring about profound changes to how teaching and learning takes place in schools ( $\mathrm{Gu} \& \mathrm{Li}$, 2013; Gu \& Day, 2015). Evidence suggests that many teachers respond to these reforms with mixed emotions (Lee \& Yin, 2011), and that some would consider leaving teaching if opportunities arose (e.g. 40\% in Liu \& Onwuegbuzie's study, 2012). In essence, this is a quality retention question. In confronting this question, we encounter a more fundamental question of how teachers view the quality of their own professional lives, and what schools and systems can do to enable them to learn to live new lives in which they are able to sustain their capacity to teach to their best over time. This fundamental question, we argue, points to the need for researching teachers' subjective wellbeing.

The present study examined, for the first time, the interrelationships between key components of teachers' subjective wellbeing. The exploration of the associations between teachers' altruistic values, efficacy beliefs, income satisfaction, and work 
satisfaction and how such associations were moderated by their income was carried to address the research question: How do the key components of teachers' subjective wellbeing relate to each other? The quantitative evidence gathered in the exploratory phase of our research reinforces the underlying assumption of the overall research project: teachers' own views of their wellbeing are not necessarily limited to happiness and pleasure. Rather, they reflect the strengths of their vocational conviction and values and their capacity to fulfil these values in their everyday worlds of work. However, values and efficacy would only have limited impact on teachers' satisfaction with work if their basic living standards were not satisfied - as measured by the average salary in the geographic areas in which they work and live. Thus, the results shed light on the importance of using a nuanced conceptual and methodological lens to understand how teachers' internal needs, values and capacity and external worlds are connected to influence the ways in which they perceive and judge the quality of their work life in teaching.

Teachers' altruistic values: seeking the inner meaning of subjective wellbeing Our research found that teachers' altruistic values have no direct associations with their income satisfaction, but direct and positive associations with work satisfaction. This finding lends strong support to the long standing observation that teaching is larger than a job. Over the last decade evidence from our own research in England and China and international surveys of teachers (OECE, 2014) shows that the majority of teachers in the profession are still hopeful, committed and passionate about making a difference to the learning and lives of the children - for whom they care and feel responsible. Bullough and Pinnegar (2009) found in their research that it is in moments when teachers were meeting their ethical obligations to children that they felt elevated and were reminded of why they were first 'called to teach'. $(2009,246)$. In present research we consider altruism as the essence of teachers' vocational values and ethical obligations, which according to Hansen (1995), enable teachers to see work as a 'service to others' and gain 'personal satisfaction in the rendering of that service' (1995, p.3). It is this inner meaningfulness intellectually, emotionally and spiritually (Palmer, 2007) - that influences, deeply and powerfully, teachers' own sense of wellbeing (Mayeroff, 1990), and concomitantly, their commitment and retention decisions. 
From the perspective of social change and evolution, Welzel and Inglehart's (2010) seminal work on values and wellbeing reminds us of the importance of considering the social markers and cultural sources of values when investigating teachers' internal worlds. This is because 'humans internalise most of their values fully unconsciously in an unquestioned process of socialization' - through which they are 'familiarised with what is socially accepted in their society' (Welzel \& Inglehart, 2010, p.47). In the Chinese culture and society where the self is viewed as 'a connected, fluid, flexible, and committed being who is bound to others' (Lu, 2010, p.335), the prevalent Confucian moral discourse has long stressed the importance of supressing selfish desires to serve the collective. Lu (2010) argues that in contrast to the Western individual-oriented conception of subjective wellbeing, the Chinese conceptions are based on individuals' fulfilment of social role obligations and thus, social-oriented. By extension, we argue that the origins of Chinese teachers' sense of purpose and meaningfulness as well as intellectual and social connections in their worlds of work reside not only in their personal motives and goals, but more profoundly, the fulfilment of their moral duties as a professional for the society. In this sense, Chinese teachers' satisfaction with the quality of their professional lives encapsulates the attainment of purpose and goals that meet both their own intrinsic professional needs and those of the larger professional community and society - to which they belong. The identification of culture-specific values in shaping Chinese teachers' perceptions of the meaning and goals of their work highlights the need for a deep understanding of what matters to whom and in what contexts in future research on teachers and teaching.

\section{Teachers' self-efficacy: the mediator of inner values in subjective wellbeing}

The direct relationship between teachers' self-efficacy and work satisfaction is not a surprising finding. As our literature review has identified, self-efficacious teachers may suffer less from stress, depression, emotional exhaustion and overall burnout. Rather, they may have more confidence in mastering challenging tasks and 'experience higher levels of personal accomplishment, commitment and job satisfaction' (Zee \& Koomen, 2016: 1007). This finding supports the recent inclusion of the eudaimonic aspects of wellbeing in the conceptual framework of subjective wellbeing - which emphasises the importance of psychological functioning in explaining human flourishing (e.g. Diener et al., 2010; Huppert \& So, 2013; OECD, 2013). 
The emerging SEM models of teachers' subjective wellbeing in our research also offer new additional evidence which shows how the two key aspects of psychological functioning (i.e. values and efficacious beliefs), individually and in combination, interactively influence teachers' perceptions of their work life. The direct and indirect paths from altruism to work satisfaction in our SEM models suggest that although strong altruistic values can fulfil teachers' satisfaction of 'becoming the kind of teacher and person they desire to be,' (Bullough \& Pinnegar, 2009: 246), the enactment and fulfilment of these values are mediated by their efficacious beliefs. On the one hand, purpose and meaning, as 'powerful regulators of human behaviour' (Welzel \& Inglehart, 2010, p. 47), empowers (or limits) individuals' efficacious beliefs in their capacity to perform proficiently in context. On the other hand, teachers need to feel efficacious in what they do in order for there to be a positive effect on work satisfaction from their strong values. In other words, only when teachers' care and love for students can be enacted in ways which enable them to 'redouble their effort to master the challenges' (Bandura, 2000, p.120) and thus continue to teach to their best can they experience higher levels of satisfaction with their work as a teacher.

\section{Teachers' income satisfaction: the 'vocation' versus 'job' debate}

In agreement with some earlier studies (Bowling, Eschleman, \& Wang, 2010; Demirel, 2014; Ignat \& Clipa, 2012), our research provides additional empirical evidence which shows that teachers' income satisfaction has positive effects on their satisfaction with work. However, what was unexpected was that the strengths of the effects (correlation coefficients between .525 and .561) appeared to be considerably higher than those from altruistic values and efficacious beliefs. In particular, the effects of altruism and selfefficacy on teachers' work satisfaction were found to be much weaker for the low-income group (.191 and .106 respectively in Figure 4) than the above-average-income group (.249 and .245 respectively in Figure 5).

The social and economic observation of the 'basic threshold' and 'relative' effects of income on individuals' life satisfaction (which we have outlined earlier in this paper) may provide plausible explanations for the difference in effect sizes identified in our research. As the International Average Salary Income Database (OECD, 2015b) shows, irrespective 
of the country's economic boom, primary and middle-school teachers' salaries in China have remained relatively low, especially compared with most other professions. Liu and Onwuegbuzie (2014) reported that the majority of surveyed teachers in their study complained about lower salaries - both in absolute terms and in comparison to many other occupations. When the fulfilment of basic needs is perceived to be the main issue, Diener \& Seligman (2004) argue that economic indicators are extremely important in determining individuals' happiness and life satisfaction outcomes.

The different associations between teachers' altruistic values, self-efficacy and work satisfaction between the low-income group and the above-average-income group provides further supporting evidence on the complex relationship between materialistic pursuits and subjective wellbeing. Both SEM models demonstrate the significant role of altruistic values and efficacious beliefs to teach well in sustaining teachers' satisfaction with the quality of their work and lives. However, they also indicate that when teachers' salaries are below the regional average salary, neither teachers' altruistic values nor their self-efficacy beliefs have a significant moderating effect on the relationship between their income satisfaction and work satisfaction. The latter observation supports Firestone's (2014) emphasis that it is important to consider basic salaries when analysing how policies which use financial incentives to improve performance may influence teacher retention: 'Teachers leave the field when they do not make competitive salaries or enough to maintain a decent living' $(2014$, p.102). The SEM model for the above-average-income group has indeed provided evidence for a counter argument, suggesting that when basic salaries are above the regional average, teachers with higher efficacious beliefs about their capabilities and with stronger altruistic values tend to report smaller effects of income on their satisfaction with work.

The exploratory study reported in this paper has several limitations. One limitation is that we measured only two dimensions of the subjective wellbeing. The affective dimension, which is comparatively less stable and not included in the SEM models in this paper, needs to be included in future examinations to develop a more nuanced measurement that affirms subjective wellbeing as 'a broad category of phenomena' (Diener et al., 1999: 277). Another limitation is that the cross-sectional nature of the study constrains the plausibility of making casual inferences. The longitudinal design of 
the main study will enable the researchers to track the changes in teacher profiles and work conditions over time, devise more reliable measurements, and draw more confident conclusions regarding the causal relationships between various constructs. Furthermore, although the exploration of the SEM models was based on existing research, there were real theoretical and practical challenges to ensure that the constructs included in the design were inclusive and that each measure conveyed a 'perfect fit' for the constructs of interest. Other measures of teacher work engagement, for example, could be considered in future research. Such challenges remind the field not to unduly simplify these complex constructs in developing quantitative measurement methods.

\section{Conclusions}

The emerging quantitative results of the study have important implications for the debate over teacher recruitment and retention.

First and foremost, they reinforce the view about teaching as a vocation, and highlight the need for policy makers and school leaders to provide optimal conditions for the effective professional development of teachers - so that they are able to continue to make a positive difference to the learning and growth of their students. In countries like China where teacher attrition is not a major issue because teaching tends to be a stable and secure career, improving the conditions for teachers' wellbeing and professional learning and development is integral to the achievement of the children.

Second, and related, they point to the differentiated effects of income on teachers' judgement of their quality of work life. There are tensions between teachers' desire to serve and the need to receive pay cheques at the end of each month which enable them to secure basic living standards. In this sense, whether teaching is a job or vocation becomes conditional. Making teachers' salaries attractive and making their conditions of work conducive to effective teaching, learning and achievement are necessary and imperative if schools in China (and beyond) are to ensure that teachers who stay in teaching are committed and passionate about giving their best to the students over the course of their professional lives. This is, as we have outlined earlier in this article, an important quality retention issue. 


\section{Reference}

Akaike, H. (1974). A new look at the statistical model identification. IEEE Transactions on Automatic Control, 19,716-723.

Ahuvia, A. (2008). If money doesn't make us happy, why do we act as if it does? Journal of Economic Psychology, 29 (4), 491-507.

Ayers, W. (2010). To Teach: The Journey of a Teacher (3 ${ }^{\text {rd }}$ edition). New York, NY: Teachers College Press.

Bandura, A. (1986) Social Foundation of Thought and Action: A Social Cognitive Theory. Englewood Cliffs, NJ: Prentice Hall.

Bandura, A. (1997). Self-Efficacy: The Exercise of Control. New York, NY: W. H. Freeman.

Bandura, A. (2000). Cultivate self-efficacy for personal and organizational effectiveness. In E. A. Locke (Ed.), Handbook of Principles of Organization Behavior (pp. 120-136). Oxford, UK: Blackwell.

Bentler, P. M. (1990). Comparative fit indexes in structural models. Psychological Bulletin, 107, 238-246.

Bogler, R. (2002). Two profiles of schoolteachers: a discriminant analysis of job satisfaction. Teaching and Teacher Education, 18 (6), 665-673.

Bowling, N. A., Eschleman, K. J., \& Wang, Q. (2010). A meta-analytic examination of the relationship between job satisfaction and subjective well-being. Journal of Occupational \& Organizational Psychology, 83, 915-934.

Browne, M. W., \& Cudeck, R. (1992). Alternative ways of assessing model fit. Sociological Methods \& Research, 21, 230-258.

Bullough, R., \& Pinnegar, S. (2009). The happiness of teaching (as eudaimonia): disciplinary knowledge and the threat of performativity. Teachers and Teaching: Theory and Practice, 15 (2), 241-256,

Bullough, R., \& Hall-Kenyon, K. (2018). Preschool Teachers' Lives and Work: Stories and Studies from the Field. New York, NY and Abingdon, Oxon: Routledge.

Canrinus, E., Helms-Lorenz, M., Beijaard, D., Buitink, J., \& Hofman, A. (2012). Self-efficacy, job satisfaction, motivation, and commitment: exploring the relationships between indicators of teachers' professional identity. European Journal of Psychology of Education, $27,115-132$.

Caprara, G., Barbaranelli, C., Steca, P., \& Malone, P. (2006) Teachers' self-efficacy beliefs as determinants of job satisfaction and students' academic achievement. Journal of School Psychology, 473-490.

Carrasco, J. G., \& Guerrero, A. B. (2008). Institución y decepción. la salubridad institucional 
y la práctica docente. Revista Española De Pedagogía, 66, 405-423.

Carsten, J.M., \& Spector, P.E. (1987). Unemployment, job satisfaction and employee turnover: A meta-analytic test of the Michinsky model. Journal of Applied Psychology, 72, 374-381.

Day, C. (2004). A Passion for Teaching. London and New York: RoutledgeFalmer.

Day, C., \& Gu, Q. (2009). Teacher emotions: wellbeing and effectiveness. In M. Zembylas and P. Schutz (Eds.). Teachers' Emotions in the Age of School Reform and the Demands for Performativity. Dordrecht: Springer, pp. 15-31.

Day, C., \& Gu, Q. (2010). The new lives of teachers. London: Routledge.

Day, C., \& Gu, Q. (2014). Resilient teachers, resilient schools: building and sustaining quality in testing times. London: Routledge. doi:10.4324/9780203578490

Day, C., Sammons, S., Stobart, G., Kington, A., \& Gu, Q. (2007). Teachers Matter. Maidenhead, Berks: Open University Press.

Demirel, H. (2014). An Investigation of the Relationship between Job and Life Satisfaction among Teachers. Procedia-Social and Behavioral Sciences, 116, 4925-4931.

De Ree, J., Muralidharan, K., Pradhan, M., \& Rogers, H. (2015). Double for nothing? Experimental evidence on the impact of an unconditional teacher salary increase on student performance in Indonesia. Working paper 21806. National Bureau of Economic Research, http://www.nber.org/papers/w21806

Diener, E. (2006). Guidelines for National Indicators of Subjective Well-Being and Ill-Being. Applied Research in Quality of Life, 1, 151-157.

Diener, E., Emmons, R. A., Larsen, R. J., \& Griffin, S. (1985). The satisfaction with life scale. Journal of Personality Assessment, 49, 71.

Diener, E., Heintzelman, S.J., Kushlev, K., Tay, L., Wirtz, D., Lutes, L., \& Oishi, S. (2017). Findings all psychologists should know from the new science on subjective well-being. Canadian Psychology, 58 (2), 87-104.

Diener, E., Lucas, R.E., \& Scollon, C.N. (2006). Beyond the hedonic treadmill: Revising the adaptation theory of well-being. American Psychologist, 61 (4), 305-314.

Diener, E., \& Seligman, M. (2004). Beyond money: Toward an economy of well-being. Psychological Science in the Public Interest, 5 (1), 1-31.

Diener, E., Suh, E.M., Lucas, R.E., \& Smith, H.L. (1999). Subjective well-being: Three decades of progress. Psychological Bulletin, 125 (2), 276-302.

Diener, E., Wirtz, D., Tov, W., Kim-Prieto, C., Choi, D., Oishi, S., \& Biswas-Diener, R. (2010). New Well-Being Measures: Short Scales to Assess Flourishing and Positive and Negative Feelings. Social Indicators Research, 97 (2), 143-156. 
Dolton, P., \& van der Klaauw, W. (1995). Leaving teaching in the UK: a duration Analysis. Economic Journal, 105, 431-444.

Evans, L. (1997). Understanding teacher morale and job satisfaction. Teaching and Teacher Education, 13 (8), 831-845.

Ferrer-i-Carbonell, A. (2002). Subjective Questions to Measure Welfare and Well-Being: A survey, Tinbergen Institute Discussion paper TI 2002-020/3, The Netherlands.

Ferrer-i-Carbonell, A. (2005). Income and wellbeing: an empirical analysis of the comparison income effect. Journal of Public Economics, 89: 997-1019.

Firestone, W. (2014). Teacher evaluation policy and conflicting theories of motivation. Educational Researcher, 43 (2), 100-107.

Firestone, W., \& Pennell, J. (1993). Teacher commitment, working conditions and differential incentive policies. Review of Educational Research, 63 (4), 489-525.

George, J.M. (1990). Personality, affect, and behaviour in groups. Journal of Applied Psychology, 75, 107-116.

Gilman, R., Huebner, E.S., Tian, L., Park, N., O’Byrne, J., Schiff, M., Sverko, D., \& Langknecht, H. (2008). Cross-national adolescent multidimensional life satisfaction reports: Analyses of mean scores and response style differences. Journal of Youth and Adolescence, 37 (2), 142-154.

Goldhaber, D. (2001). Significant, but Not Decisive. Education Matters, 1 (2), 61-65.

Goodlad, J. (2004) A Place Called School. New York, NY: McGraw-Hill.

Goodlad, J. I., Soder, R., \& Sirotnik, K. A. (1990). Places Where Teachers are Taught. CA: Jossey-Bass.

$\mathrm{Gu}, \mathrm{Q}$. (2014). The work and lives of teachers in china. London: Routledge.

$\mathrm{Gu}, \mathrm{Q}, \& \mathrm{Li}, \mathrm{Q}$. (2013). Sustaining resilience in times of change: stories from chinese teachers. Asia pacific Journal of Teacher Education, 41(3), 288-303. doi:10.1080/1359866X.2013.809056

Hansen, D. (1995). The Call to Teach. New York, NY: Teacher College Press.

Hanushek, E.A. (2006). Teacher quality. In E. A. Hanushek \& F. Welch (Eds.), Handbook of the Economics of Education (pp. 1052-1078). New York and Oxford, Elsevier.

Haybron, D. (2008). Philosophy and the science of subjective well-being. In M. Eid \& R. Larsen (Eds.), The Science of Subjective Well-Being (pp.17-43). New York and London: The Guilford Press.

Higgins, C. (2011). The Good Life of Teaching: An Ethics of Professional Practice. Chichester, 
West Sussex: Wiley-Blackwell.

Helliwell, J., Layard, R., \& Sachs, J. (2015). World Happiness Report 2015. New York, HY: Sustainable Development Solutions Network.

Helliwell, J.F., \& Wang, S. (2011). Weekends and Subjective Well-Being. Working Paper, No. 17180, National Bureau of Economic Research, Cambridge MA.

Hoy, W. K., \& Woolfolk, A. E. (1990). Organizational socialization of student teachers. American Education Research Journal, 27, 279-300.

Hu, L. T., \& Bentler, P. M. (1999). Cutoff criteria for fit indexes in covariance structure analysis: Conventional criteria versus new alternatives. Structural Equation Modeling, 6, $1-55$.

Huberman, M. (1993). The Lives of Teachers. Falmer: Continuum.

Huppert, F.A., \& So, T. (2013). Flourishing across Europe: Application of a new conceptual framework for defining well-being. Social Indicators Research, 110 (3), 837-861.

Ignat, A., \& Clipa, O. (2012). Teachers' satisfaction with life, job satisfaction and their emotional intelligence. Procedia - Social and Behavioral Sciences, 33, 498-502.

Ingersoll, R. M. (2002). The teacher shortage: A case of wrong diagnosis and wrong perception. NASSP Bulletin, 86 (631), 16-31.

Ingersoll, R. M., \& May, H. (2012). The magnitude, destinations, and determinants of mathematics and science teacher turnover. Educational Evaluation and Policy analysis, 34, 435-464.

Johnson, S.M., \& Birkeland, S. E. (2003). Pursuing a "sense of success": New teachers explain their career decision. American Educational Research Journal, 40, 581-617.

Judge, T., Bono, J., Erez, A., \& Locke, E. (2005). Core self-evaluations and job and life satisfaction: The role of self-concordance and goal attainment. Journal of Applied Psychology, 90 (2), 257-268.

Kahneman, D., \& Krueger, A. (2006). Developments in the measurement of subjective wellbeing. The Journal of Economic Perspectives, 20, 3-24.

Kelley, C. J., \& Finnigan, K. (2003) The effects of organisational context on teacher expectancy. Educational Administration Quarterly, 39 (5), 603-634.

Klassen, R. M., \& Chiu, M. M. (2010). Effects on Teachers' Self-Efficacy and Job Satisfaction: Teacher Gender, Years of Experience, and Job Stress. Journal of Educational Psychology, 102 (3), 741-756.

Klassen, R.M., Tze, V.M., Betts, S.M., \& Gordon, K. A. (2011). Teacher efficacy research 19982009: signs of progress or unfulfilled promised? Educational Psychological Review, 23, 2143. 
Klein, A., \& Moosbrugger, H. (2000). Maximum likelihood estimation of latent interaction effects with the LMS method. Psychometrika, 65, 457-474.

Klein, A. G., \& Muthén, B. O. (2007). Quasi-maximum likelihood estimation of structural equation models with multiple interaction and quadratic effects. Multivariate Behavioral Research, 42, 647-673.

Lee, J.C., \& Yin, H.B. (2011). Teachers' emotions and professional identity in curriculum reform: A Chinese perspective. Journal of Educational Change, 12, 25-46.

Liu, S., \& Onwuegbuzie, A.J. (2012). Chinese teachers' work stress and their turnover intention. International Journal of Educational Research, 53, 160-170.

Liu, S., \& Onwuegbuzie, A. J. (2014). Teachers' motivation for entering the teaching profession and their job satisfaction: a cross-cultural comparison of China and other countries. Learning Environments Research, 17, 75-94.

Loeb, S., \& Page, E. (2000) Examining the link between teacher wages and student outcomes. The Review of Economics and Statistics, 82 (3), 393-408.

Lu, L. (2010). Chinese wellbeing. In M.H. Bond (Ed.), The Oxford Handbook of Chinese Psychology (pp. 327-342). Oxford: Oxford University Press.

Lucas, R.E. (2007). Long-term disability is associated with lasting changes in subjective well-being: Evidence from two nationally representative longitudinal studies. Journal of Personality and Social Psychology, 92 (4), 717-730.

Lucas, R.E. \& Lawless, N.M. (2013). Does life seem better on a sunny day? Examining the association between daily weather conditions and life satisfaction judgements. Journal of Personality and Social Psychology, 104 (5), 872-884.

Marchesi, E. (2007). When words are not the world. Krankenpfl Soins Infirm, 100, 20-22.

Marsh, H., Hau, K., \& Wen, Z. (2004). In search of golden rules: comment on hypothesistesting approaches to setting cutoff values for fit indexes and dangers in overgeneralizing $\mathrm{Hu}$ and Bentler's (1999) findings. Structural Equation Modelling: A Multidisciplinary Journal, 11 (3), 320-341.

Mayeroff, M. (1990). On Caring. New York: Harper Perennial.

McKinney, P. A. (2000). A study to assess the relationships among student achievement, teacher motivation, and incentive pay. Unpublished doctoral dissertation, University of Blacksburg, Virginia.

Miles, D.E., Borman, W.E., Spector, P.E., \& Fox, S. (2002). Building an integrative model of extral role work behaviours: A comparison of counter-productive work behaviour with organisational citizenship behaviour. International Journal of Selection and Assessment, 10, 51-57. 
Murnane, R., \& Cohen, D.K. (1986) Merit pay and the evaluation problem: why most merit pay plans fail and a few survive. Harvard Educational Review, 56 (1), 1-17.

Murnane, R.J., \& Olsen, R.J. (1989). The Effects of Salaries and Opportunity Costs on Duration in Teaching: Evidence from Michigan. The Review of Economics and Statistics, 71 (2), 347-352.

Murnane, R.J., \& Olsen, R.J. (1990). The Effects of Salaries and Opportunity Costs on Length of Stay in Teaching: Evidence from North Carolina. The Journal of Human Resources, 25 (1), 106-124.

Muthén L, K., \& Muthén, B. O. (2008-2011). Mplus user's guide. Los Angeles, CA: Authors.

Muthén, B. O., \& Satorra, A. (1995). Complex ample data in structural equation modeling. In P. V. Marsden (Ed.), Sociological methodology (pp. 267-316). Washington DC: American Sociological Association.

Nias, J. (1989). Primary Teachers Talking. London: Routledge.

Nieto, S. (2003). What Keeps Teachers Going? New York, NY: Teachers College Press.

Nieto, S. (2015). Why We Teach Now? New York, NY: Teachers College Press.

Noddings, N. (1992). The Challenge to Care in Schools. New York: Teachers College Press.

OECD [The Organization for Economic Cooperation and Development] (2013). OECD Guidelines on Measuring Subjective Well-being. Paris: OECD Publishing.

OECD [The Organization for Economic Cooperation and Development] (2014). TALIS 2013 Results: An International Perspective on Teaching and Learning. Paris: OECD Publishing.

OECD [The Organization for Economic Cooperation and Development] (2015a). How's Life? 2015 Measuring Well-being. Paris: OECD Publishing.

OECD [The Organization for Economic Cooperation and Development] (2015b). OECD Economic Surveys: China 2015. Paris: OECD Publishing.

OECD [The Organization for Economic Cooperation and Development] (2016). Supporting Teacher Professionalism: Insights from TALIS 2013. Paris: OECD Publishing.

OECD [The Organization for Economic Cooperation and Development] (2017). PISA 2015 Results: Students' Well-being. Paris: OECD Publishing.

Palmer, P. (2007). The Courage to Teach (10 th edition). New York, NY: Jossey-Bass.

Pavot, W., \& Diener, E. (2008). The satisfaction with life scale and the emerging construct of life satisfaction. Journal of Positive Psychology, 3, 137-152.

Pillay, H., Goddard, R., \& Wilss, L. (2005). Well-being, burnout and competence 
Implications for teachers. Australian Journal of Teacher Education, 30, 22-33.

Pyhältö, K., Soini, T., \& Pietarinen, J. (2010). Pupils' pedagogical well-being in comprehensive school - significant positive and negative school experiences of Finnish ninth graders. European Journal of Psychology of Education, 25 (2): 207-221.

Raykov, T. (2004). Point and interval estimation of reliability for multiple component measuring instruments via linear constraint covariance structure modelling. Structural Equation Modeling: A Multidisciplinary Journal, 11 (3), 342-356.

Renshaw, T. L., Long, A. C. J., \& Cook, C. R. (2015). Assessing adolescents' positive psychological functioning at school: development and validation of the student subjective wellbeing questionnaire. School Psychology Quarterly, 30 (4), 534-552.

Ryan, R. M., \& Deci, E. L. (2001). On happiness and human potentials: a review of research on hedonic and eudaimonic well-being. Annual Review of Psychology, 2001, 521 (1), 141166.

Schwarz, G. (1978). Estimating the dimension of a model. The Annals of Statistics, 6, 461464.

Schwarz, G. \& Alberts, J. (1998) Teacher Lore and Professional Development for School Reform. Westport, CT: Bergin \& Garvey.

Schwerdtfeger, A., Konermann, L., \& Schönhofen, K. (2008). Self-efficacy as a healthprotective resource in teachers? A biopsychological approach. Health Psychology Official Journal of the Division of Health Psychology American Psychological Association, 27, 358.

Seligman, M.E.P. (2011). Flourish. London and Boston: Nicholas Brealey Publishing.

Shen, J., Leslie, J., Spybrook, J.K., \& Ma, X. (2012) Are principal background and school processes related to teacher job satisfaction? American Educational Research Journal, 49 (2), 200-230.

Skaalvik, E., \& Skaalvik, S. (2010). Teacher self-efficacy and teacher burnout: A study of relations. Teaching and Teacher Education, 26, 1059-1069.

Skaalvik, E., \& Skaalvik, S. (2011). Teacher job satisfaction and motivation to leave the teaching profession. Teaching and Teacher Education, 27 (6), 1029-1038.

Spector, P.E. (1997). Job satisfaction: Application, Assessment, Cause, and Consequences. Thousand Oaks, CA: Sage.

The Children's Society (2013). The Good Childhood Report 2013. London: The Children's Society.

The Children's Society (2015). The Good Childhood Report 2015. London: The Children's Society.

The Children's Society (2016). The Good Childhood Report 2016. London: The Children's 
Society.

Tov, W., \& Diener, E. (2007). Culture and subjective well-being. In S. Kitayama \& D. Cohen (Eds.), Handbook of Cultural Psychology (pp. 691-713). New York: Guilford.

Tucker, L. R., \& Lewis, C. (1973). A reliability coefficient for maximum likelihood factor analysis. Psychometrika, 38, 1-10.

Veenhoven, R. (1991). Is happiness relative? Social Indicators Research, 24, 1-34.

Veenhoven, R. (2000). Freedom and happiness: a comparative study in forty-four nations in the early 1990s. In E. Diener \& E. Suh (Eds.), Culture and Subjective Wellbeing (pp. 257288). Cambridge, Massachusetts: The MIT Press.

von der Embase, N.P., Sandilos, L., Pendergast, L., \& Mankin, A. (2016). Teacher stress, teaching-efficacy, and job satisfaction in response to test-based educational accountability policies. Learning and Individual Differences, 50, 308-317.

Welzel, C., \& Inglehart, R. (2010). Agency, values, and well-being: A human development model. Social Indicators Research, 97 (1), 43-63.

Wen, Z. L., Marsh, H. W., \& Hau, K. T. (2010). Structural equation models for latent interactions: an appropriate standardized solution and its scale-free properties. Structural Equation Modelling, 17, 1-22.

Wu, V., \& Short, P. (1996) The relationship of empowerment to teacher job commitment and satisfaction. Journal of Instructional Psychology, 23 (1), 85-89.

$\mathrm{Xu}, \mathrm{X}$. (2007). An empirical on teachers' work values and its effects. Unpublished PhD Thesis, Chongqing: Southwestern University.

$\mathrm{Xu}, \mathrm{X}$., \& Zhang, D. (2011). The relationship between teachers' work value and job performance. Journal of Psychological Science, 34 (4), 871-874.

Yuan, K. H., \& Schuster, C. (2013). Overview of statistical estimation methods. In Little, T. D. (Ed.), The Oxford Handbook of Quantitative Methods, Volume 1, Foundation (pp. 361387). New York: Oxford University Press.

Yuan, K., Le, V., McCaffrey, D., Marsh, J., Hamilton, L., Stecher, B., \& Springer, M. (2013). Incentive pay programs do not affect teacher motivation or reported practices: results from three randomized studies. Educational Evaluation and Policy Analysis, 35 (1), 3-22.

Zee, M. \& Koomen, H.M.Y. (2016) Teacher self-efficacy and its effects on classroom processes, student academic adjustment, and teacher wellbeing: A synthesis of 40 years of research. Review of Educational Research, 86 (4), 981-1015.

Zhang, J., Yang, Z., \& Ling, H. (2014). Work stress, job satisfaction and job burnout in primary and middle schools teachers. Chinese Journal of Clinical Psychology, 22 (5), 920922. 
Table 1. Demographics of the initial survey participants

\begin{tabular}{|c|c|c|}
\hline & $\mathrm{N}$ & Percentage \\
\hline \multicolumn{3}{|l|}{ Gender } \\
\hline Female & 1130 & $74.1 \%$ \\
\hline Male & 395 & $25.9 \%$ \\
\hline \multicolumn{3}{|l|}{ School type } \\
\hline Primary & 1002 & $65.7 \%$ \\
\hline Secondary & 523 & $34.3 \%$ \\
\hline \multicolumn{3}{|l|}{ Teaching experiences } \\
\hline 1-5 years & 398 & $26.1 \%$ \\
\hline 6-10 years & 290 & $19.0 \%$ \\
\hline 11-20 years & 557 & $36.5 \%$ \\
\hline 21-30 years & 238 & $15.6 \%$ \\
\hline 30 years or above & 42 & $2.8 \%$ \\
\hline \multicolumn{3}{|l|}{ Educational degree } \\
\hline High School & 9 & $0.6 \%$ \\
\hline Semi-Bachelor & 200 & $13.1 \%$ \\
\hline Bachelor & 1215 & $79.7 \%$ \\
\hline Master or above & 101 & $6.6 \%$ \\
\hline \multicolumn{3}{|l|}{ Income } \\
\hline$R M B ¥ 1000$ or below (GBP 100 or below) & 15 & $1.0 \%$ \\
\hline$R M B ¥ 1000-3000(G B P 100-300)$ & 693 & $45.4 \%$ \\
\hline$R M B ¥ 3001-5000(G B P 301-500)$ & 727 & $47.7 \%$ \\
\hline$R M B ¥ 5000$ above(GBP500 above) & 90 & $5.9 \%$ \\
\hline
\end{tabular}


Table 2. Descriptive statistics of the raw scores, latent factor correlations and latent factor score reliability $(\mathrm{N}=1,525)$

\begin{tabular}{|c|c|c|c|c|}
\hline Factor & 1. & 2. & 3. & 4. \\
\hline 1. Altruism & - & & & \\
\hline 2. Income satisfaction & $.032^{\mathrm{ns}}$ & - & & \\
\hline 3. Self-efficacy & $.307^{* *}$ & $.128^{* *}$ & - & \\
\hline 4. Work satisfaction & $.245^{* *}$ & $.572^{* *}$ & $.301^{* *}$ & - \\
\hline Mean & 4.326 & 3.079 & 3.944 & 3.731 \\
\hline SD & .847 & 1.038 & 1.118 & .940 \\
\hline Scale score composite reliability $(\omega)$ & .951 & .870 & .937 & .914 \\
\hline
\end{tabular}


Table 3. The estimates of the standardized structural regression coefficients for all SEM models

\begin{tabular}{|c|c|c|c|c|}
\hline & $\begin{array}{c}\text { Model 1: Total sample } \\
(\mathrm{N}=1525)\end{array}$ & $\begin{array}{l}\text { Model 2: Total sample } \\
\quad(\mathrm{N}=1525)\end{array}$ & $\begin{array}{l}\text { Model 3: Low income } \\
(<3000)(\mathrm{N}=708)\end{array}$ & $\begin{array}{l}\text { Model 4: High income } \\
(>3000)(\mathrm{N}=817)\end{array}$ \\
\hline \multicolumn{5}{|l|}{ Direct effect } \\
\hline$A L \rightarrow W S$ & $.172^{* *}$ & $.181^{* *}$ & $.106^{* *}$ & $.245^{* *}$ \\
\hline$\rightarrow W S$ & $.550^{* *}$ & $.561^{* *}$ & $.591^{* *}$ & $.525^{* *}$ \\
\hline$\rightarrow W S$ & $.189^{* *}$ & $.225^{* *}$ & $.191^{* *}$ & $.249^{* *}$ \\
\hline$\rightarrow E F$ & $.308^{* *}$ & $.307^{* *}$ & $.268^{* *}$ & $.346^{* *}$ \\
\hline \multicolumn{5}{|l|}{ Moderating effect } \\
\hline$A L \times I S \quad \rightarrow \quad W S$ & $\mathrm{~N} / \mathrm{A}$ & $-.100^{* *}$ & -.043 ns & $-.153^{* *}$ \\
\hline$E F \times I S \rightarrow W S$ & $\mathrm{~N} / \mathrm{A}$ & $-.090^{* *}$ & $-.072 \mathrm{~ns}$ & $-.099 * *$ \\
\hline
\end{tabular}

Note: ${ }^{\text {ns }}$ - not statistically significant ( $\left.\mathrm{p}>.05\right) ;{ }^{* *}-\mathrm{p}<.01 ; \mathrm{N} / \mathrm{A}=$ Not available; $\mathrm{WS}=$ work satisfaction; $\mathrm{IS}=$ income satisfaction; $\mathrm{AL}=\mathrm{altruistic}$ value to teaching and students; $\mathrm{EF}=$ Self-efficacy. 
Table 4. Measurement invariance and latent mean difference relevant to low-income and above-average-income groups

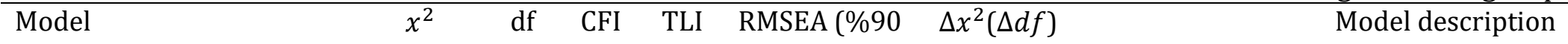

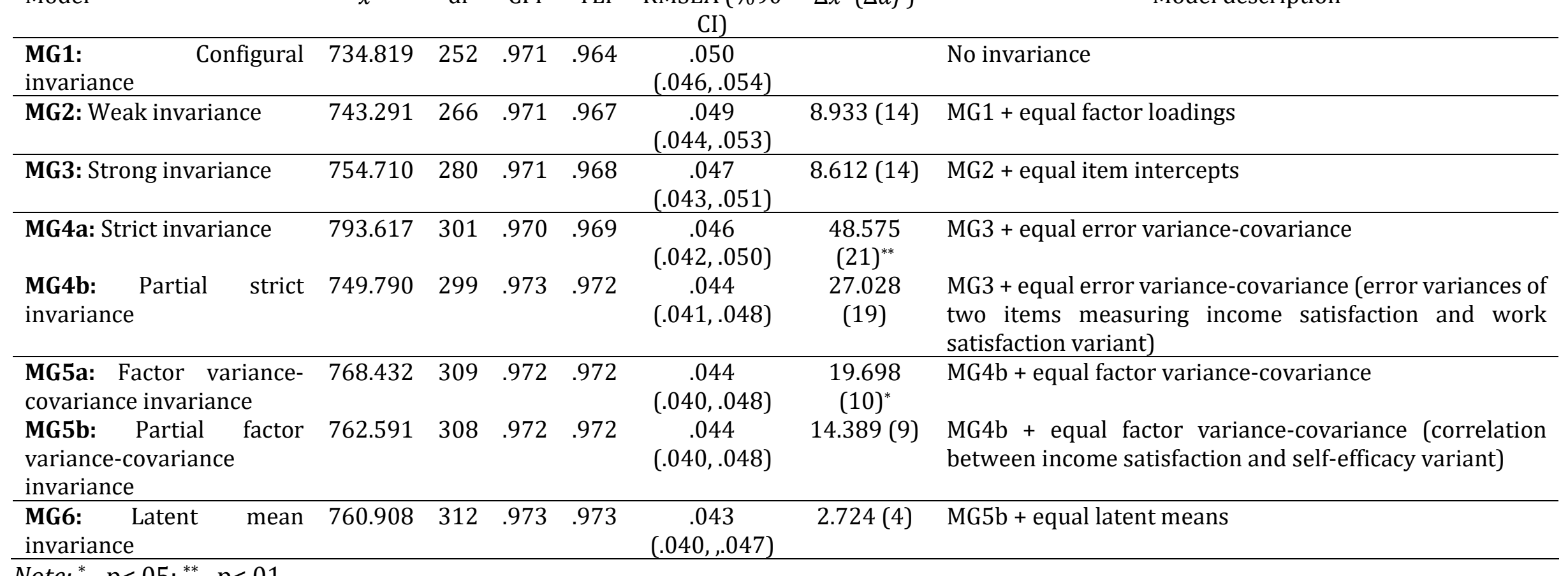




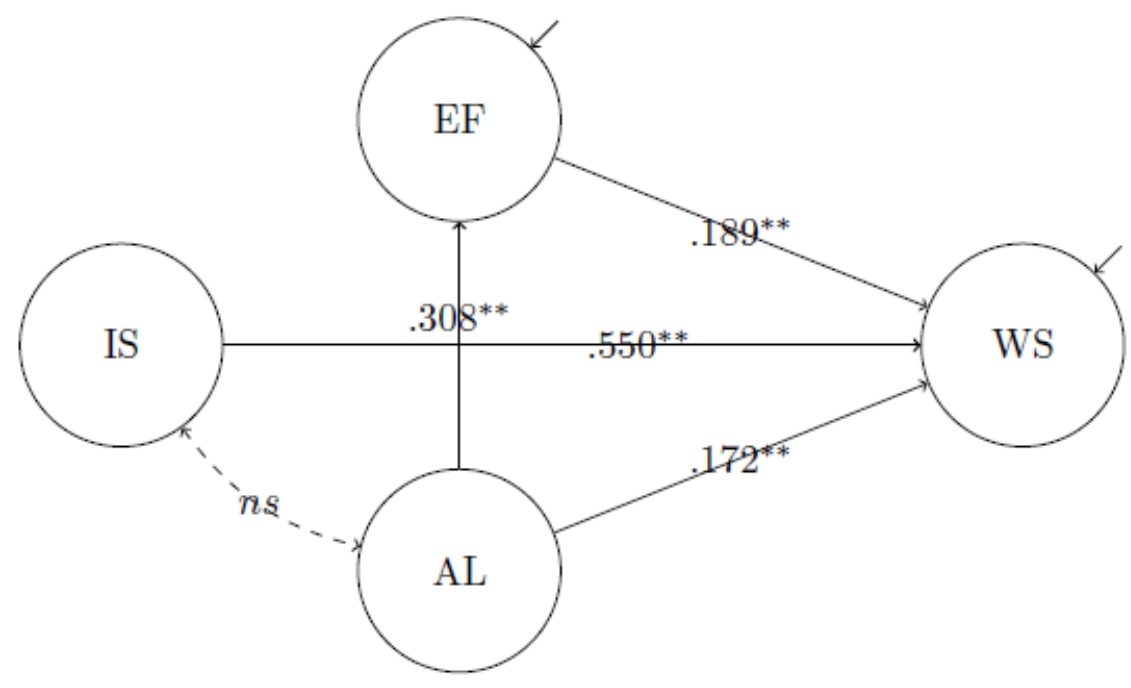

Figure 1. Model 1 - Effects of altruism, satisfaction to income, and self-efficacy on work satisfaction: mediating roles of self-efficacy $(\mathrm{N}=1525)$

Note: ${ }^{* *}-\mathrm{p}<.01 ;$ ns - not statistically significant (dashed line); $\mathrm{AL}=$ altruistic value to teaching and students; IS = income satisfaction; EF = self-efficacy; WS = work satisfaction.

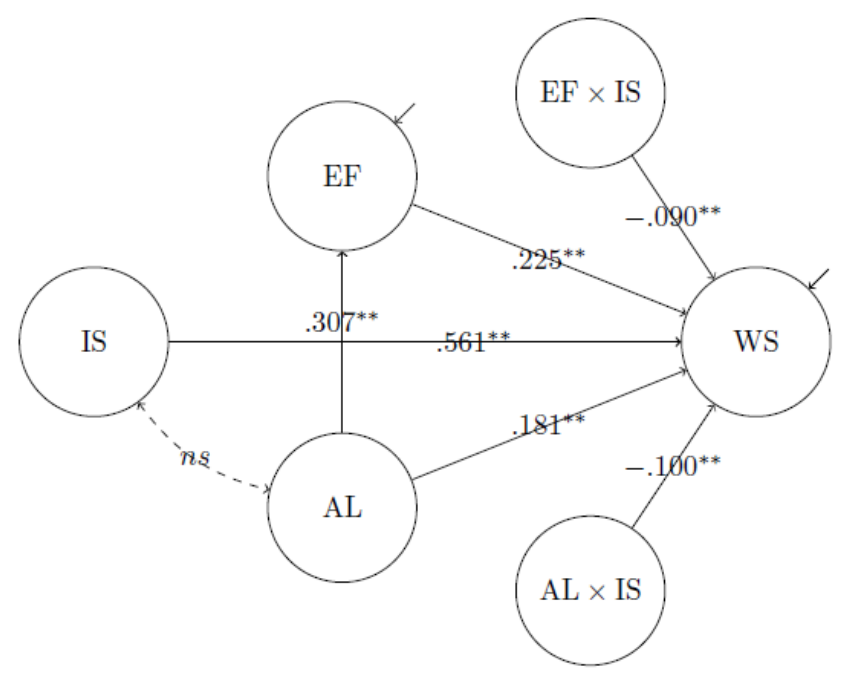

Figure 2. Model 2 - Effects of altruism, satisfaction to income, and self-efficacy on work satisfaction: moderating effects for the total sample $(\mathrm{N}=1525)$

Note: ${ }^{*}-\mathrm{p}<.05 ;^{* *}-\mathrm{p}<.01 ;{ }^{\text {ns }}$ - not statistically significant (dashed line); AL = altruistic value to teaching and students; IS = income satisfaction; $\mathrm{EF}=$ self-efficacy; $\mathrm{WS}=$ work satisfaction; AL x IS = interaction term between altruistic value to teaching and students and income satisfaction; EF x IS = interaction term between self-efficacy and income satisfaction. 

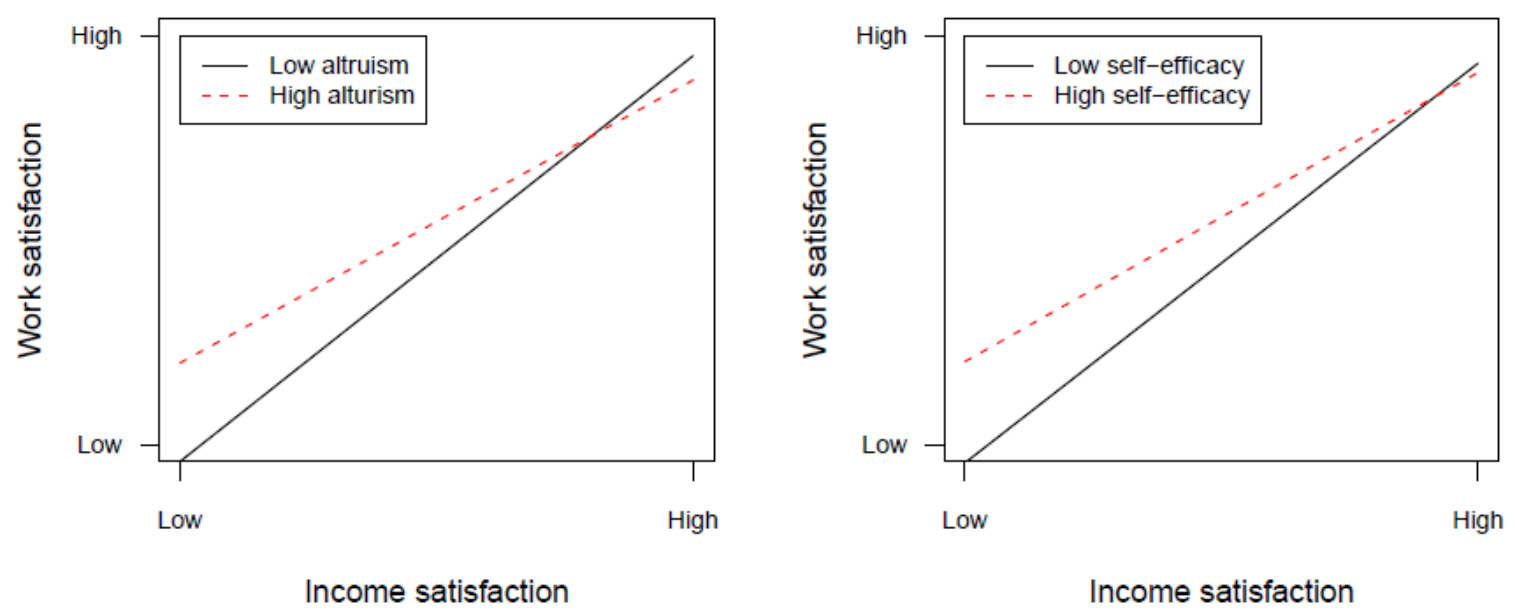

Figure 3. Illustrations of the moderating effects of altruism and self-efficacy on the influence of income satisfaction on work satisfaction $(\mathrm{N}=1,525)$ 


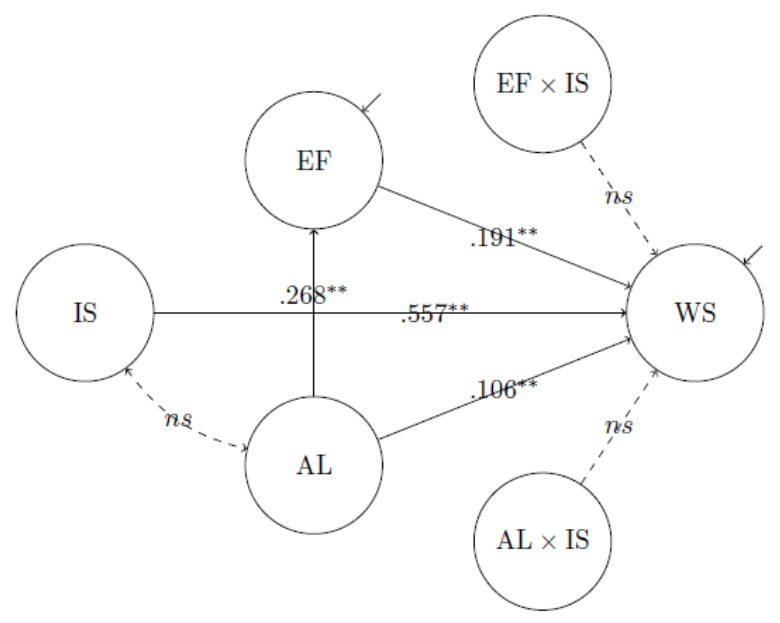

Figure 4. Model 3 - Effects of altruism, satisfaction to income, and self-efficacy on work satisfaction: moderating effects for the low-income group ( $\mathrm{N}=708)$

Note: ${ }^{* *}-\mathrm{p}<.01 ;$ ns - not statistically significant (dashed line); AL = altruistic value to teaching and students; IS = income satisfaction; EF = self-efficacy; WS = work satisfaction; AL x IS = interaction term between altruistic value to teaching and students and income satisfaction; EF x IS = interaction term between self-efficacy and income satisfaction.

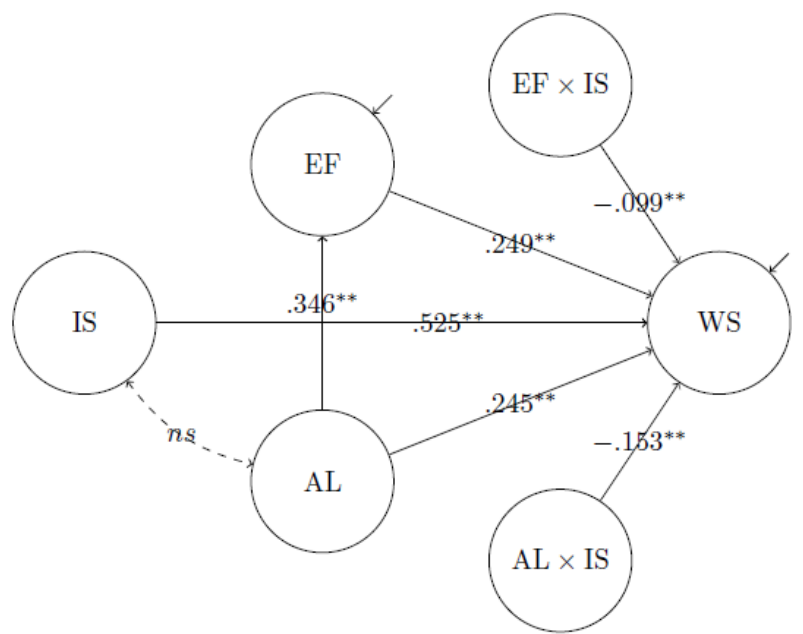

Figure 5. Model 4 - Effects of altruism, income satisfaction, and self-efficacy on work satisfaction: moderating effects for the high-income group $(\mathrm{N}=817)$

Note: ${ }^{* *}-\mathrm{p}<.01$; ns - not statistically significant (dashed line); $\mathrm{AL}=$ altruistic value to teaching and students; IS = income satisfaction; EF = self-efficacy; WS = work satisfaction; AL x IS = interaction term between altruistic value to teaching and students and income satisfaction; EF x IS = interaction term between self-efficacy and income satisfaction. 
